\title{
Functional Anatomy of the Olfactory Organ in the Fresh Water Teleost, Heteropneustes Fossilis (BL.)
}

\author{
By \\ HEM RAJ GOEL \\ Zoology Research Laboratories, Multanimal Modi College, Modinagar (U. P.), India \\ -Received for Publication, July 20, 1978-
}

Key Words: Comparative anatomy, Olfactory organ, Teleost.

\begin{abstract}
Summary. The anatomical and histological studies of the olfactory organ of the fresh water fish- $H$. fossilis were performed in the adult specimens. The olfactory chambers are paired, situated antero-dorsally on either side of the middle line of snout. Each olfactory chamber communicates outside by an anterior and a posterior nasal openings. The anterior opening is tubular while the posterior is simple and oval. The accessory nasal sac is absent but the median raphe is present. Each lamella bears a linguiform process.

The epithelium of the olfactory lamella comprises supporting, olfactory receptor (primary and secondary neurons), basal and goblet cells. Synapses are formed between the primary and secondary neurons. Basal cells differentiate into the olfactory receptor cells and the supporting cells. Goblet cells are mainly present on the free margin of the epithelium.
\end{abstract}

The structure of the olfactory organ in the teleostean fishes has been earlier described by a number of workers. The notable references related to the problem are of Burne (1909), Adrian and Ludwig (1938), Allison (1953), Baradi and Bourne (1953), Iwai and Nakamura (1964), Pfeiffer (1964 and 1965), Bannister (1965), Andres (1966), Frisch (1967), Wilson and Westerman (1967), Gemne and Doving (1969), Kapoor and Ojha (1971), Graziadei and Metcalf (1971), Singh (1972) and Ojha and Kapoor (1973). Keeping in view that only a few Indian species have been investigated so far, the work of this nature was undertaken to execute studies on this topic to enrich information regard- ing the functional anatomy of the olfactory organ in the Heteropneustes fossilis-a fresh-water, air-breathing teleost.

\section{Material and Methods}

The heads of alive $H$. fossilis were fixed in $10 \%$ formalin or aqueous Bouin's fluid. The fish was dissected from the dorsal side to expose the olfactory apparatus and the brain to establish the relationship between the two. The olfactory rosettes were taken out and number of olfactory lamellae was counted under a stereoscopic microscope. The measurements of the rosettes and the 
fish were noted. The lamellae were fixed in aqueous Bouin's solution for 12 hours or Zenker's fluid for 8 hours. Serial transverse sections of Bouin's fixed lamellae were cut at $4-6 \mu$ and stained in Harrish's haematoxylin (counter stained with eosin) or Zenker fixed lamellae in Mallory's triple stain. Sections stained with Mallory's triple stain gave best results.

\section{Observations}

The olfactory organs of $H$. fossilis consist of paired olfactory chambers situated on the anterodorsal surface of the head slightly below the level of the eyes. The anterior and posterior nasal opening lie at a distance from one another and mark the anterior and posterior boundaries of the olfactory chambers. The anterior nasal opening is situated on a forwardly and outwardly directed tube, while the posterior nasal opening is oval and valvular (Fig. 1). A dissection of the head from the dorsal side shows the anatomical relationship of the brain to the olfactory rosettes. The olfactory rosettes can be seen lying separated from each other along the mid-dorsal line by the mesethmoid bone. The olfactory bulbs are globular structures lying at the caudal end of the olfactory rosettes and receive bundles of olfactory fibres emerging from the ventral surface of the corresponding rosettes. They are connected with the telencephalic lobes by a narrow and elongated olfactory tracts (Fig. 2).

The olfactory chamber with its rosette is lodged in a pit formed in the ethmoidal region of the skull. The entire cavity of the olfactory chamber is occupied by an elongated olfactory rosette. On the dorsal surface of the olfactory rosette is seen the median raphe; it is formed by an infolding of the ventral wall of the olfactory chamber present along the long axis of the olfactory rosette from its anterior to posterior end. On either side of the median raphe are arranged a large number of thin, closely set, foliaceous and laterally compressed olfactory lamellae (Fig. 3). The ventral margin of each lamella is attached to the wall of the olfactory chamber and its proximal end is attached to the median raphe. The dorsal margin of each la-

Table 1. Number and the surface area of the olfactory lamellae in $H$. fossilis.

\begin{tabular}{rrrrrr}
\hline S. No. & $\begin{array}{l}\text { Length of } \\
\text { the fish } \\
\text { in mm. }\end{array}$ & $\begin{array}{l}\text { Number of } \\
\text { lamellae } \\
\text { in the left } \\
\text { rosette }\end{array}$ & $\begin{array}{l}\text { Number of } \\
\text { lamellae } \\
\text { in the right } \\
\text { rosette }\end{array}$ & $\begin{array}{l}\text { Total number } \\
\text { of lamellae } \\
\text { in both } \\
\text { rosettes }\end{array}$ & $\begin{array}{l}\text { Total surface } \\
\text { area of lamellae } \\
\text { in both rosettes } \\
\text { in sq. mm. }\end{array}$ \\
\hline 1 & 124 & 34 & 35 & 69 & 2760 \\
2 & 126 & 35 & 35 & 70 & 2830 \\
3 & 95 & 26 & 26 & 52 & 1900 \\
4 & 162 & 50 & 50 & 100 & 4710 \\
5 & 123 & 34 & 34 & 68 & 2962 \\
6 & 165 & 53 & 54 & 107 & 4782 \\
7 & 140 & 44 & 44 & 88 & 3838 \\
8 & 90 & 25 & 25 & 50 & 1750 \\
9 & 142 & 44 & 45 & 89 & 3900 \\
10 & 151 & 52 & 52 & 104 & 4550 \\
\hline Average & 132 & 40 & 40 & 80 & 3371 \\
\hline
\end{tabular}


mella possesses well developed linguiform process at its distal end (Fig. 4). The processes of the lamellae are directed towards the periphery of the rosette where they form the peripheral channel between them and the wall of the olfactory chamber. The olfactory lamellae of the middle region of the olfactory rosette are largest while they decrease in size towards anterior as well as posterior ends. Since the smallest lamellae are present on the extreme anterior and posterior ends, it implies that new lamellae are added in the rosette at the two ends. Adult specimens of varying size were selected to determine the number of olfactory lamellae and the surface area of their epithelium present in each of their olfactory rosette. The observations are recorded in the accompanying table-1. It is evident from the readings of the table- 1 that the total number of lamellae along with the surface area are directly proportional to the size of the fish.

After cutting the integument of dorsal surface of olfactory chamber and turning it over, a clear area is seen on the inner side which has the same dimensions as that of olfactory rosette. It has a prominent median ridge and a channel all along its length. The anterior nasal opening communicates at the anterior end by this channel. The aforesaid ridge and its channel cover the central part of the rosette. The peripheral channel of the olfactory rosette is covered by a groove of the peripheral part of the integument. The posterior nasal opening communicates inside with the grooved peripheral channel and outside with the exterior (Fig. 5).

Each olfactory lamella consists of a sensory olfactory epithelium and a central lamellar space, the central core. The olfactory epithelium is very thick and comprises following types of cells :
Supporting or sustentacular cells

These cells are elongated and columnar in shape which are arranged in a regular layer. This layer of supporting cells forms the most superficial layer. These cells are wider towards the outer side and narrower towards the inner side. Each cell bears a large oval and poorly stained nucleus. The tips of the supporting cells bear faintly visible cilia which are attached with the basal bodies (Fig. 6).

\section{Olfactory receptor cells}

These cells are the sensory elements of the olfactory epithelium and are differentiated into primary neurons and secondary neurons. The primary neurons are closely arranged beneath the supporting cells and are distinguished by their rounded and darkly stained nuclei situated in the centre of cells. The axonal ends of a few primary neurons synapse with the dendritic tips of the secondary neurons are characterised by deeply stained oval and elongated nuclei. These cells are present in 1-2 layers lying below the primary neurons (Fig. 6 and 7).

\section{Basal cells}

These cells are a few and scattered in the deepest layers of the olfactory epithelium. They are oval, pear-shaped and rounded in appearance containing darkly stained nuclei. These cells migrate towards the upper layers of the olfactory epithelium and are believed to form the reservoir for the formation of olfactory receptor cells and the supporting cells (Fig. 6 and 7 ).

Goblet or mucin secreting cells

These cells are abundantly present in the superficial layer of the olfactory epithelium particularly at its free margin. They are swollen, ovoid and 
rounded bodies. As the goblet cells pass through different stages of secretory activity they present a wide variation in their form and appearance (Fig. 6).

\section{Central core}

It is lined by a well developed basement membrane. It is filled with loose connective tissue containing blood capillaries, and nerve fibres (Fig. 6).

The flow of current in $H$. fossilis is unidirectional. It enters the anterior nasal opening and passes out through the posterior nasal opening after bathing the olfactory rosette. It can be confirmed by introducing the carmine particles into the nasal chamber through the anterior nasal opening of an alive fish held under water and observed through the stereoscopic binocular microscope, a small amount of red coloured water is seen coming out of the posterior nasal opening. It clearly implies that the activity of cilia present on the tubular anterior opening and on the sensory epithelium is able to create slow current of water across the olfactory chamber. The well developed linguiform processes of the lamellae are directed towards the periphery of the rosette and divide the dorsal concave surface of the rosette into a central part and a peripheral channel. By this type of morphological arrangement of the lamellae of the rosette, water entering the anterior nasal opening is conducted over the central part of the rosette which then flows to its peripheral channel and ultimately passes out by means of posterior nasal opening.

\section{Discussion}

The presence of anterior nasal opening in $H$. fossilis on a forwardly and outwardly directed tube confirms the observations of Burne (1909) that tubular anterior openings are chiefly, though not exclusively, found in eels (besides flat fishes, siluroids and snakeheads). Kapoor and Ojha (1971) reported anterior opening on the forwardly and outwardly directed tube in Muraena undulata and Cynoglossus oligolepis. Singh (1972) described circular, oval and slit-like posterior nasal openings in a number of fishes. Besides these, crescent shape of posterior nostril is also mentioned by Burne (1909) in salmons, herrings and carps. In $H$. fossilis the posterior nasal opening is oval and valvular. The anterior and posterior nasal openings are situated at a little distance in $H$. fossilis while Pfeiffer (1964) observed in Hoplopagrus guentheri that the anterior opening is situated close to the mouth while the posterior opening is widely separated from the anterior opening and located close to the eye. The axis of the rosette in $H$. fossilis is longitudinal and continuous to the frontal tip of the anterior nostril. This is also reported by Singh (1972) in Bagarius bagarius, Botia dario and Chatoessus manminna. In Colisa, however, the axis lies transversely (Singh 1972). The lamellae of $H$. fossilis are thin, flattened, foliaceous and laterally compressed with linguiform processes while considerable differences are found in the shape of the lamellae of other fishes. The lamellae are elongated in Bagarius bagarius and Botia dario, domeshaped in Colisa fasciatus and of fingerlike structure in Chatoessus manminna (Singh 1972). According to Burne (1909) the lamellae may be claw-like in shape (Salmonidae, Clupeidae), convex (Mugil, Perca, Pagellus), triangular (eel) in out line. Iwai and Nakamura (1964) observed that the nasal lamellae in olfactory rosette differ in shape from species to species in Tunas.

It has been observed in $H$. fossilis that the number and surface area of lamellae 
in olfactory rosettes are directly proportional to the size of the fish and this has also been observed by preiffer (1965) in Lota lota. The accessory nasal sac is absent in $H$. fossilis which is recorded by Kapoor and Ojha (1971) in Labeo rohita and Cynoglossus oligolepis.

The epithelium of olfactory lamella consists of the supporting, olfactory receptor, basal and goblet cells. The supporting cells of $H$. fossilis bear short and faintly visible cilia. Ciliated supporting cells have been reported in the olfactory epithelium of the lamellae in Fitzroyia lineata (Trujilo-Cenoz, 1961), Hybopsis aestivalis, Hybopsis gelida (Branson, 1963), Thunnus obesus (Iwai and Nakamura, 1964), Bagarius bagarius, Xenentodon cancila, Botia dario, Colisa fasciatus (Singh, 1972) and Labeo rohita (Ojha and Kapoor, 1973). Non-ciliated supporting cells have been described in Katsuwonus pelamis (Gooding, 1963), Phoxinus, Gastrerosteus (Bannister, 1965), Lota lota (Gemne and Doving, 1969) and Chatoessus manminna (Singh, 1972).

The most remarkable feature of the olfactory epithelium of $H$. fossilis is the presence of secondary neurons and the occurrence of synaptic connections between the primary and the secondary neurons. The presence of synapses in the olfactory epithelium have so far been reported by Ojha and Kapoor (1973) in Labeo rohita with whom our findings agree. It is a widely accepted view that the synaptic formation occurs only in the olfactory bulb but not in the olfactory epithelium. In the olfactory bulb the axons of the primary neurons synapse with the dendrites of the mitral cell.

The basal cells are present deep in the olfactory epithelium just above the basement membrane and have been reported in all vertebrates by Allison (1953), Baradi and Bourne (1953), Andres (1966), Frisch (1967), Gemne and Doving
(1969) and Ojha and Kapoor (1973). In $H$. fossilis, the basal cells occupy the similar positions. It has been recently reported by Graziadei and Metcalf (1971) that the basal cells are able to differentiate into the receptor cells while Ojha and Kapoor (1973) observed their transformation into supporting cells. In $H$. fossilis, the basal cells are present in the upper part of the olfactory epithelium which probably form the olfactory receptor cells and supporting cells. Adrian and Ludwig (1938), Bannister (1965) and Wilson and Westerman (1967) have observed the presence of mucous secreting goblet cells in the fishes. In $H$. fossilis, these cells of varying sizes and shapes are present in the olfactory epithelium.

\section{Acknowledgments}

The author expresses his deep sense of gratitude to Dr. O.P. Saxena for going through the manuscript and suggestions. Thanks are also due to Dr. S. D. Loiwal, Principal, for providing laboratory facilities.

\section{References}

1) Adrian, E.D. and Ludwig, C.: Nervous discharges from the olfactory organs of fishes. J. Physiol., $94:$ 441-460, 1938.

2) Allison, A.C.: The morphology of the olfactory system in the verterbrates. Biol. Rev., 28 : 195-244, 1953.

3) Andres, K.H.: Der Feinbau der Regio olfactoria von Makrosmatikern. $Z$. Zellforsch., 69 : 140-154, 1966.

4) Bannister, L.H.: The fine structure of the olfactory surface of teleostean fishes. Quart. J. Micr. Sci., 106 : 333-342, 1965.

5) Baradi, A.F. and Bourne, G.H.: Gustatory and olfactory epithelia. Intern. Rev. Cytol., 2: 289-330, 1953.

6) Branson, B.A.: The olfactory apparatus of Hybopsis qelida and Hybopsis aestivalis. J. Morph., 113 : 215-229, 1963. 
7) Burne, R.H.: The anatomy of the olfactory organs of teleostean fishes. Proc. Zool. Soc. Lond., 2: 619-663, 1909.

8) Frisch, D.: Ultrastructure of mouse olfactory mucosa. Am. J. Anat., 121: 87-120, 1967.

9) Gemne, G. and Doving, K. B.: Ultrastructural properties of primary olfactory neurons in fish, Lota lota. Am. J. Anat., 126 : 457-476, 1969.

10) Gooding, R.M.: The olfactory organ of the skipjack, Katsuwonus pelamis. FAO Fish Rept., 3 : 1621-1631, 1963.

11) Graziadei, P.P.C. and Metcalf, J.F. Autoradiographic and ultrastructural observations on the frog's olfactory mucosa. Z. Zellforsch. 116: 305-318, 1971.

12) Iwai, T. and Nakamura, I.: Olfactory organs of Tunas, with special reference to their systematic significance. Bull. Misaki Mar. Bio. Inst. Kyoto Univ., 7 : 1-8, 1964.

13) Kapoor, A.S. and Ojha, P.P.: Structure of the note in some Indian teleostean fishes. Curr. Sci., 20 : 550-551, 1971.

14) Kubiak, H.: The blood vessels of the olfactory organ in the silver beam, Blicca bjorkna. Acta Biol. Cracoviensia, Ser. Zool. 5, $57:$ 66, 1962.

15) Ojha, P.P. and Kapoor, A.S.: Histology of the olfactory epithelium of the fish, Labeo rohita. Arch. Biol., 44 : 425-441, 1973.

16) Pfeiffer, W.: The morphology of the olfactory organ of Hoplopagrus guentheri Gill. Can. J. Zool., 42: 235-237, 1964.

17) Pfeiffer, W.: The size of the olfactory organ in the burbot, Lota lota. Can. J. Zool., 43 : 223-224, 1965.

18) Singh, C.P.: A comparative study of the olfactory organ of some Indian fresh water teleostean fishes. Anat. Anz., Bd. 131 : 225-233, 1972.

19) Trujillo-Cenoz, O.: Electronmicroscopic observations on chemo-and mechanoreceptor cells of fishes. Z. Zellforsch., 54 : 654-676, 1961.

20) Wilson, J.A.F. and Westerman, R.A. The fine structure of the olfactory mucosa and nerve in the teleost, Carassius carassius. Z. Zellforsch., 83: 196206, 1967. 


\section{PLATES}




\section{Explanation of Figures}

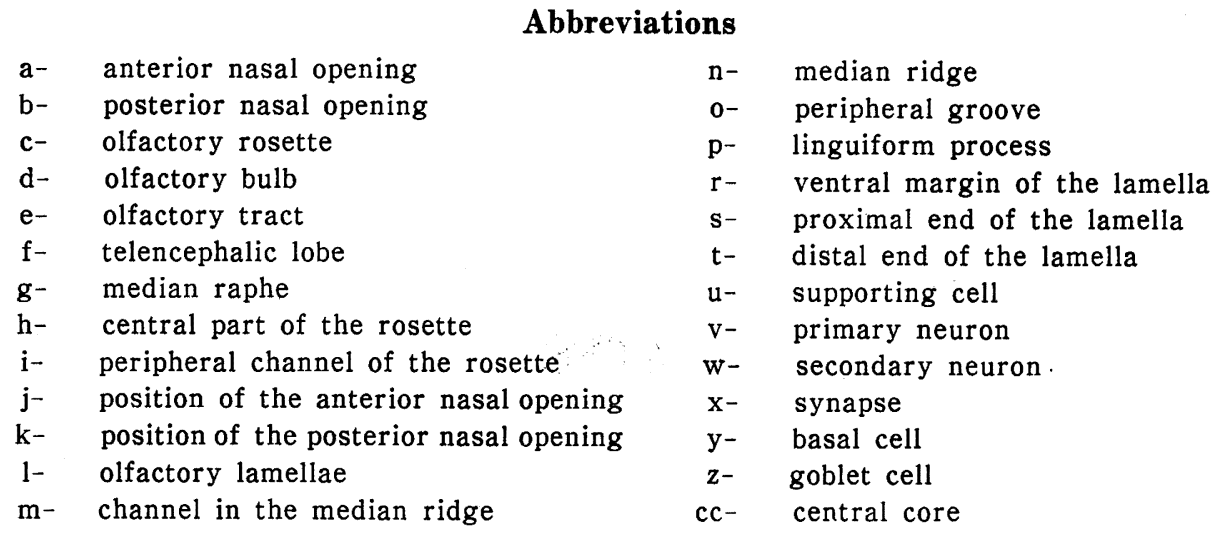

\section{Plate I}

Fig. 1. Dorsal view of the head of $H$. fossilis to show the nasal openings.

Fig. 2. Dissection of the head of $H$. fossilis from the dorsal side to show the relationship o: brain with the olfactory rosettes.

Fig. 3. Dorsal view of the olfactory rosette of $H$. fossilis.

Fig. 4. Dorsal view of the olfactory rosette and the inner side of the integument covering the rosette after it has been turned over in $H$. fossilis. 

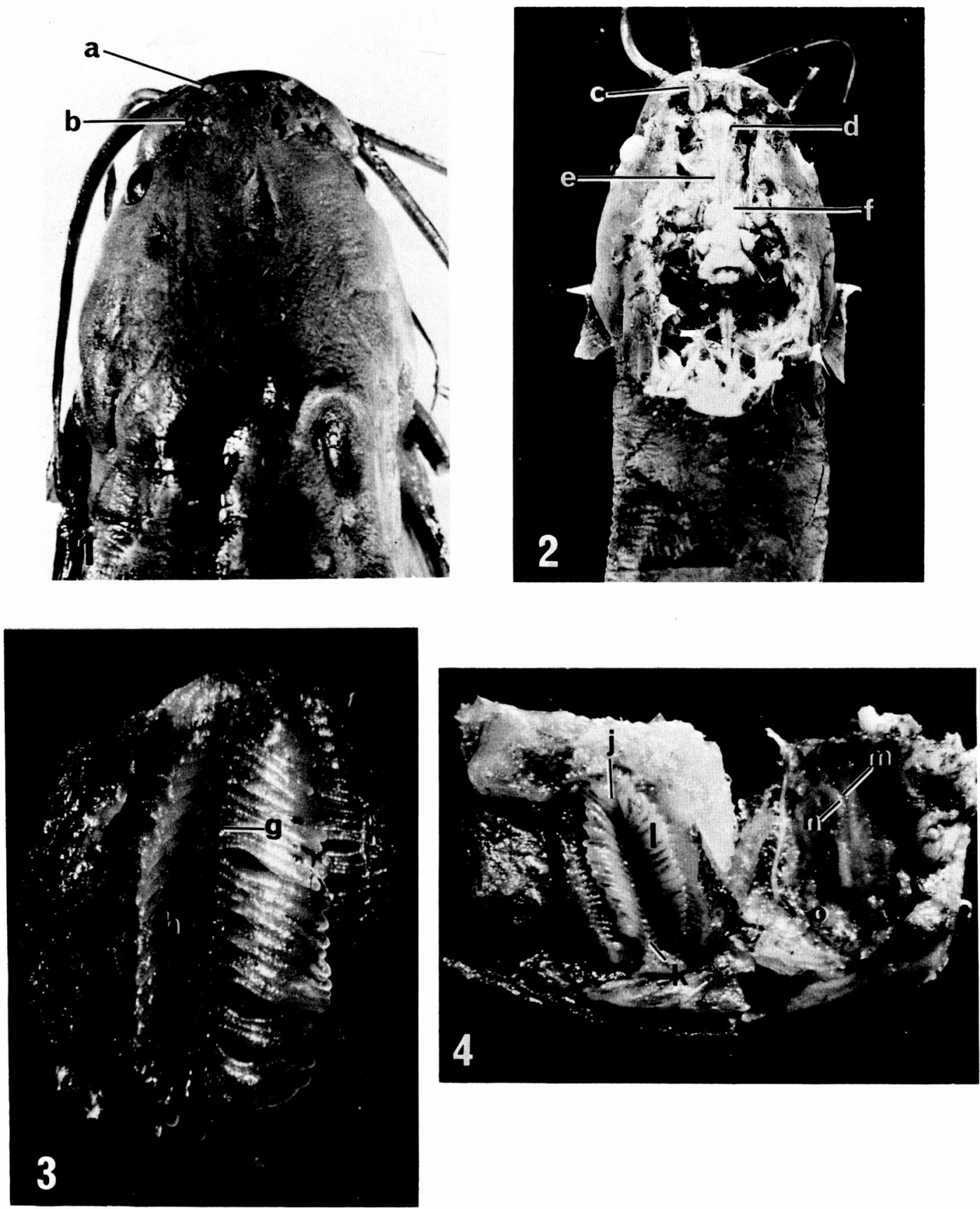


\section{Plate II}

Fig. 5. Photomicrograph of an olfactory lamella of H. fossilis. $\times 100$

Fig. 6. Photomicrograph of a T.S. of olfactory lamella of $H$. fossilis, showing arrangement of various types of cells. $\times 400$

Fig. 7. Photomicrograph of a part of an olfactory lamella of H. fossilis, showing synapse. $\times 1000$ 


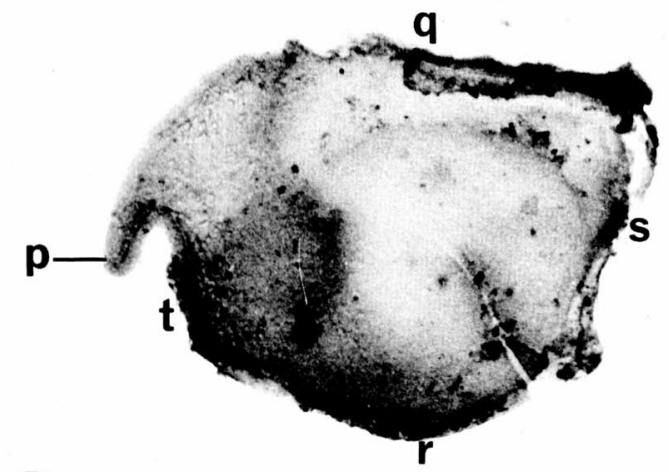

5
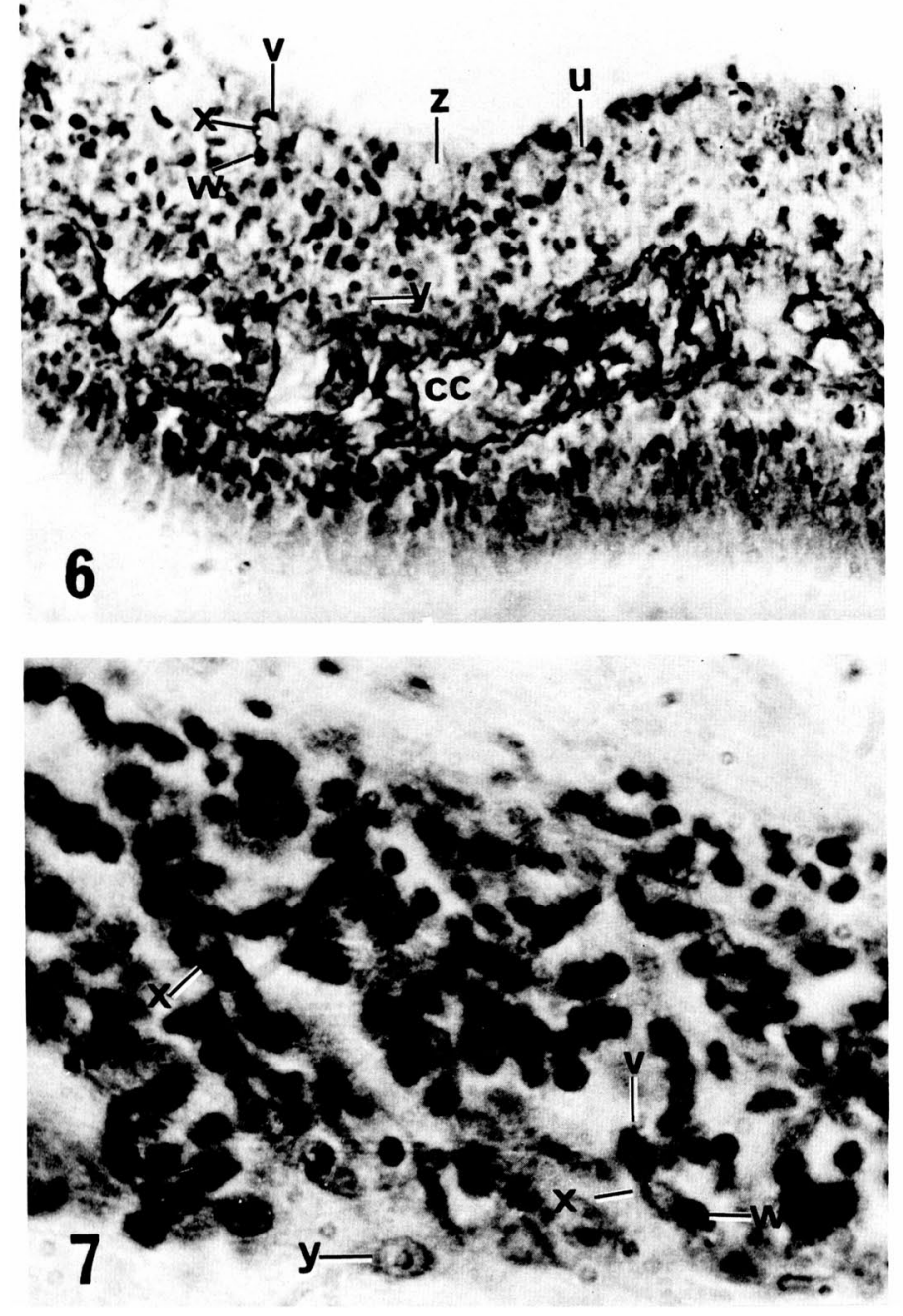